\title{
Belatacept and CD28 Costimulation Blockade: Preventing and Reducing Alloantibodies over the Long Term
}

\author{
Ronald F. Parsons ${ }^{1} \cdot$ Christian P. Larsen $^{1} \cdot$ Thomas C. Pearson $^{1} \cdot$ I. Raul Badell ${ }^{1}$ \\ Published online: 2 November 2019 \\ (C) Springer Nature Switzerland AG 2019
}

\begin{abstract}
Purpose of Review Highlight developments in T and B cell biology that are helping elucidate the mechanisms underlying CD28 pathway blockade-mediated inhibition of alloantibodies in transplantation, and discuss recent clinical observations on the impact of belatacept on de novo and established HLA antibodies.

Recent Findings The identification of $\mathrm{T}$ follicular helper cells as the CD4+ T cell subset required for optimal humoral immunity, along with newly identified roles for CD28 and the B7 molecules on B cell lineage cells, has begun to pave the way for improved understanding and discovery of the mechanisms of CD28 costimulation blockade-mediated antibody inhibition. There has been resurgent clinical interest in the ability of belatacept to attenuate alloantibody responses. New reports have continued to document its ability to prevent de novo antibody responses, and more recent studies have surfaced exploring its potential to control nascent or pre-existing HLA antibodies.

Summary A growing understanding of the mechanisms of anti-CD28-mediated alloantibody inhibition and continued clinical successes will guide the clinical optimization of belatacept and next-generation CD28 blockers to prevent and reduce alloantibodies over the long term.
\end{abstract}

Keywords Belatacept $\cdot$ Alloantibodies $\cdot$ Costimulation blockade $\cdot$ Kidney transplantation $\cdot$ CD28 pathway $\cdot$ CTLA-4-Ig

\section{Introduction}

Over the past several decades, advances in solid organ transplantation have significantly reduced acute rejection rates and improved short-term kidney allograft survival. However, long-term outcomes following kidney transplantation remain suboptimal [1, 2]. Historically, late kidney allograft failure was chiefly attributed to calcineurin inhibitor toxicity and chronic allograft nephropathy [3], but it is now well recognized that donor-specific HLA antibodies are an important immunologic cause of acute and chronic allograft injury that shorten renal allograft survival [4]. These donor-specific antibodies (DSA) either exist pre-transplant or arise de novo after transplant and are associated with inferior transplant outcomes $[5,6]$. Despite the prevalence and deleterious impact of HLA antibodies in kidney transplantation, therapies that reliably

I. Raul Badell

ibadell@emory.edu

1 Emory Transplant Center, 101 Woodruff Circle, Suite 5105 WMB, Atlanta, GA 30322, USA control pathologic DSA, prevent antibody-mediated premature allograft loss, and result in improved survival rates have not been developed [7].

Current de novo DSA rates after kidney transplantation are 15-20\% with CNI-based immunosuppression [8], and the majority of clinical regimens aimed at pre-formed HLA antibodies or de novo DSA have targeted B cells (e.g., rituximab, bortezomib) or the antibodies themselves (e.g., IVIG, plasmapheresis) $[9,10]$. While current long-term outcomes are acceptable and the field has observed some encouraging shortterm results with these desensitization strategies, significant long-term control of HLA antibody-mediated graft dysfunction and loss has not been achieved. Hypotheses to explain this dilemma include inadequate inhibition of humoral alloimmunity by mainstay CNIs over the long-term and that conventional desensitization approaches target B cells and DSA once they have already developed, leaving the upstream cellular processes that underlie alloantibody production largely unaddressed. Thus, current methods may be "too little, too late" in and of themselves, and the introduction of therapeutics that better address the $\mathrm{T}: \mathrm{B}$ cell interactions that have been increasingly recognized as key mediators of de novo and 
recall antibody responses as part of regimens aimed at combating HLA antibodies for long-term efficacy are greatly needed [8].

The advent of costimulation blockade in 2011 with FDA approval of belatacept for maintenance immunosuppression in kidney transplantation introduced the opportunity of utilizing costimulation blockade-based strategies to combat HLA antibodies in the clinic. The ability of belatacept and its predecessor abatacept (CTLA-4-Ig) to inhibit humoral immune responses was very evident early in the clinical development process. Experimental data with CD28 costimulation blockade showed excellent prevention of alloantibodies in experimental mouse and nonhuman primate transplant models [9-11]. In humans, not only does belatacept hold promise in its potential to improve long-term outcomes by reducing off-target toxicities [12], but importantly, it has also been associated with lower rates of de novo DSA formation [13*0]. While the ability of CTLA-4-Ig to induce tolerance and control acute cellular rejection is diminished with increasing immune complexity in large animal models and humans $[14$, 15], it has consistently maintained its ability to control alloantibody responses from mice to humans.

As the only costimulation blocker approved for transplantation, belatacept is currently finding its way into broader scale clinical practice. However, we recently reported effective long-term use of costimulation blockade with abatacept (approved for use in rheumatoid arthritis) in a small series of CNI intolerant renal transplant recipients [16], and early phase clinical trials are underway with next-generation selective CD28 costimulation blocking agents by our group and others [17]. Therefore, costimulation blockade as an immunosuppressive strategy, either in the form of belatacept, its predecessor abatacept, or next-generation selective CD28 blockade, is poised to be instrumental in the development of novel methods of combating and reducing the detrimental impact of HLA antibodies in transplantation over the long term.

Here, we review new developments in $\mathrm{T}$ and $\mathrm{B}$ cell biology that are helping close knowledge gaps regarding the mechanisms underlying CD28 pathway blockademediated inhibition of DSA following transplantation and discuss recently published clinical observations on the impact of belatacept on de novo and established HLA antibodies. It is becoming increasingly evident that a growing understanding of the cellular mechanisms responsible for DSA formation and maintenance following transplantation is synergizing with early clinical results observed with belatacept in a variety of clinical settings to guide the optimization of current immunosuppressive strategies and the development of novel therapies to control alloantibodies.

\section{Underlying mechanisms of antibody inhibition}

Since the discovery that CD28-deficient mice exhibit significantly impaired immunoglobulin concentrations and class switching, and do not undergo the proliferative expansion necessary for germinal center (GC) formation $[18,19]$, the mechanisms underlying the effectiveness of therapeutic CD28 pathway blockade to prevent antibody responses have not been entirely understood. Although long-standing experimental evidence has supported that costimulation blockade of the CD28 pathway with CTLA-4-Ig is an effective means of preventing alloantibody formation after transplantation [9-11], recent identification of $\mathrm{T}$ follicular helper (Tfh) cells, a newly defined CD4+ T cell subset required for optimal B cell help and long-lived humoral immunity [20], along with newly identified roles for $\mathrm{CD} 28$ and the $\mathrm{B} 7$ molecules on $\mathrm{B}$ cell lineage cells, has begun to pave the way for improved understanding and discovery of the mechanisms of CD28-mediated antibody inhibition (Fig. 1).

\section{Impact of CD28 costimulation blockade on Tfh cells}

CD28 costimulation blockade has long been known to deprive $\mathrm{T}$ cells of the second, or costimulatory signal required for complete $\mathrm{T}$ cell activation, thus rendering them apoptotic or anergic [21]. Newfound knowledge of Tfh cells and the influence of costimulatory and coinhibitory signals on their biologic behavior has recently been elucidated with an increasing interest in Tfh cells as the targets of CD28 costimulation blockade-mediated alloantibody inhibition in transplantation $[22,23]$. Tfh cells are responsible for optimum antibody production, in that they provide $\mathrm{T}$ cell help to $\mathrm{B}$ cells for GC formation, affinity maturation, and the generation of memory $\mathrm{B}$ cells and long-lived plasma cells to effectuate an adequate humoral immune response [20]. Tfh cells are heavily dependent on the costimulatory molecule CD28 in that they rely on CD28 signaling for differentiation and GC formation, and loss of CD28 results in inadequate $\mathrm{T}$ cell-dependent antibody responses.

With this knowledge, several investigators have demonstrated that CTLA-4-Ig or belatacept controls Tfh cellmediated humoral responses in both mice and monkeys. Kim et al. provided immunological characterization of de novo and recall alloantibody suppression by CTLA-4-Ig in a mouse model of allosensitization [24]. They observed that CTLA-4-Ig reduced Tfh cell and GC responses and inhibited de novo DSA in mice following skin transplantation, as well as abrogated recall DSA upon re-sensitization. In a NHP kidney transplant model of antibody-mediated rejection, belatacept prevented early DSA and was associated with fewer class-switched B cells and Tfh-like cells in the peripheral blood of transplanted monkeys, along with attenuated GC 


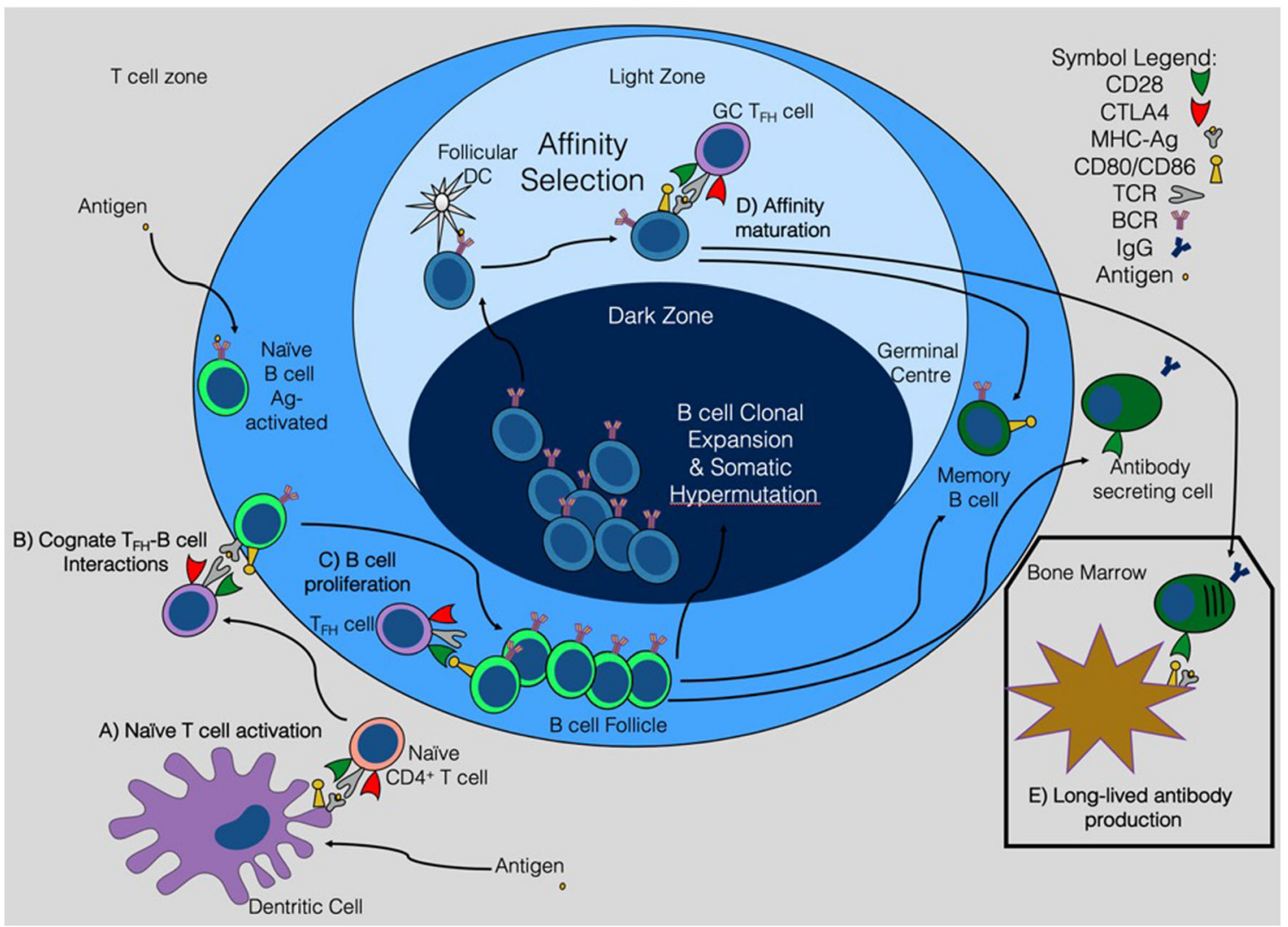

Fig. 1. Targets of CD28:B7 pathway blockade to inhibit alloantibody production. The identification of Tfh cells and newly discovered roles for CD28 and the B7 molecules on B cell lineage cells has improved our mechanistic understanding of CD28 costimulation blockademediated inhibition of alloantibody production. CD28 blockade interferes with naïve $\mathrm{CD} 4+\mathrm{T}$ cell activation and Tfh cell differentiation (A). Targeting the CD28:B7 axis also potentially disrupts early cognate

responses in the lymph nodes $\left[25^{\circ}\right]$. Collectively, these findings suggest belatacept-mediated control of the humoral alloimmune response via inhibition of Th cells.

Belatacept (and CTLA-4-Ig) inhibits T cell activation by binding the ligands CD80 and CD86 to prevent their engagement with the $\mathrm{T}$ cell costimulator $\mathrm{CD} 28$ on multiple cell types. This mechanism of action also blocks CD80 and CD86 ligation of the coinhibitory molecule CTLA-4, potentially depriving $\mathrm{T}$ cells of important inhibitory signals and interactions [26]. CTLA-4-deficient mice exhibit lethal lymphoproliferative disease characterized by hypergammaglobulinemia [27], and more recent data from the Sharpe and Sakaguchi labs have shown that CTLA-4 critically regulates multiple aspects of the GC reaction $\left[28^{*}, 29^{\circ *}\right]$. Thus, the influence of CD28 costimulation and CTLA-4 coinhibition on antibody production supports the use of selective CD28 blockade that spares CTLA-4 coinhibitory activity to tilt the net balance of stimulatory and inhibitory signaling in favor of improved control of Tfh-mediated DSA production. Accordingly, we recently showed that selective CD28 blockade with a novel anti-
Tfh:B cell interactions (B) along with directly inhibiting activated B cell proliferation $(\mathrm{C})$ and differentiation into other downstream $\mathrm{B}$ cell lineage cells. Additionally, anti-CD28 therapy may interfere with GC Tfh and B cell interactions that drive the affinity maturation process (D), as well as memory B cell and antibody-secreting cell differentiation and function. Once established, alloantibody production may rely on CD28-dependent survival of long-lived plasma cells residing in the bone marrow (E)

CD28 domain antibody that lacks the Fc domain leads to superior inhibition of donor-specific $\mathrm{Tfh}$ cell and antibody responses relative to CTLA-4-Ig in a murine transplant model $\left[30^{\circ}\right.$ ]. Graft-elicited GC B cells were also better inhibited by the selective blocker, and donor-reactive $\mathrm{Tfh}$ cells exhibited differentially high levels of CTLA-4 expression. Ville et al. also tested a selective anti-CD28 antibody in a NHP model of kidney transplantation and showed similar inhibition of DSA as compared to belatacept, but less incidence of acute rejection [31]. In exploring the mechanisms responsible for these observations, the authors identified a trend of higher graftinfiltrating Treg frequencies in anti-CD28-treated animals, as well as increased gene expression levels of the Tfhassociated cytokine IL-21 in belatacept-treated animals. The anti-CD28 antibody was more effective at controlling human $\mathrm{Tfh}$ cell proliferation in vitro and secondary $\mathrm{Tfh}$ cell responses in a mouse antigen immunization model. Furthermore, ongoing work in our laboratory has revealed that improved inhibition of Tfh-mediated humoral alloimmunity with selective CD28 blockade versus 
CTLA-4-Ig is CTLA-4-dependent and intrinsic to Tfh:B cell cognate interactions [32].

Overall, recent findings from several laboratories have implicated the inhibition of Th cells as an important associated mechanism of CD28 costimulation blockade-mediated alloantibody prevention. Additional studies with selective CD28 blockers that leave CTLA-4 coinhibitory activity intact on Tfh cells may provide an additional mechanistic advantage over CTLA-4-Ig or belatacept in controlling DSA responses. Upcoming pilot clinical trials evaluating the efficacy of the selective anti-CD28 antibody lulizumab (Bristol-Myers Squibb) in renal transplantation will provide valuable new data on the real impact of this strategy on alloantibody formation in human transplant recipients.

\section{CD28:B7 axis and B cells}

CD28 has long been considered a prototypical $\mathrm{T}$ cell costimulatory molecule and not recognized to have any functional role on cells of the $\mathrm{B}$ cell lineage. However, there is now growing evidence to suggest that the $\mathrm{CD} 28: \mathrm{B} 7$ axis has a functional role in B cells and that costimulation blockade may at least in part be exerting its anti-humoral effects through the inhibition of memory and antibody-secreting B cells.

As previously noted, CTLA-4-Ig has been uniformly effective at controlling de novo DSA responses via its ability to inhibit naive $\mathrm{CD} 4+\mathrm{T}$ cell activation and $\mathrm{T}$ cell-dependent antibody responses in transplantation [9-11]. In a series of reports from the Chong Lab, CTLA-4-Ig successfully reversed ongoing or inhibited established allo-specific B cell responses in murine allosensitization models $\left[33,34^{\circ}, 35\right]$. Utilizing a novel technique to track endogenous antigenspecific B cells following sensitization with allogeneic cells, delayed administration of CTLA-4-Ig 7 days postimmunization dissolved established germinal centers and halted further development of alloantibodies [33]. In sensitized mice, CTLA-4-Ig inhibited alloreactive memory B cells with the intrinsic ability to preferentially differentiate into ASCs and recapitulate the recall alloantibody response after rechallenge with a heart transplant $\left[34^{* *}\right]$. Interestingly, delayed CTLA-4-Ig after heart transplant reduced the alloreactive B cell response, inhibited alloantibody production, and prevented acute rejection in this same model [35]. The inhibition of DSA and rejection was seemingly T cellindependent and could be reversed with hyperimmune sera, implicating CTLA-4-Ig susceptible B cells as the chief mediators of antibody production and rejection in this model.

In addition to the impact Stanley Jordan's lab showed CTLA-4-Ig has on Tfh cells [24], abatacept also inhibited $\mathrm{CD} 138+$ plasma cell IgG production in vivo and directly suppressed antibody production by a plasma cell-like IgG1-secreting mouse hybridoma cell line in vitro. Further in vitro studies on human cells by Leibler et al. showed that belatacept exerts a direct inhibitory effect on plasmablast differentiation, Ig production, and the plasma cell transcription factor blimp-1 [36], as well as induce intrinsic signaling within B cells and reduce their expression of CD86. In this study, belatacept also disrupted $\mathrm{Tfh}$ cell activation in autologous Tfh-memory B cell ex vivo co-cultures, suggesting that control of humoral responses with CTLA-4-Ig in kidney transplant recipients consists of both $\mathrm{T}$ and $\mathrm{B}$ cell-intrinsic effects.

In the hematology/oncology field, the Lee Lab has reported that sustained antibody responses depend on CD28 function in long-lived plasma cells that reside in the bone marrow [37"*], and has begun to elucidate the molecular basis for the prosurvival effect of $\mathrm{CD} 28$ signaling on this unique subset of antibody-secreting cells [38]. They observed CD28 to be expressed on both short- and long-lived plasma cells in mice, but CD28-driven enhanced survival occurred only in the longlived subset in a plasma cell-intrinsic manner. In vivo, even in the presence of sufficient $\mathrm{T}$ cell help, loss of CD28 or its ligands CD80 and CD86 caused significant loss of the longlived plasma cell population, reduction of their half-life, and inability to maintain long-term antibody titers. Consistent with these mouse data, detailed examination of plasma cells in human bone marrow identified CD28 expression on $20 \%$ of a subset of long-lived plasma cells uniquely capable of secreting antibodies specific for measles and mumps viruses more than 40 years after infection [39]. Alternatively, Njau et al. have published data suggesting that CD28 deficiency may in fact promote plasma cell function [40]. Under different experimental conditions, plasma cell frequencies and antibody titers were enhanced in mice with plasma cells lacking CD28 in response to antigen immunization and influenza virus infection. It is possible that the $\mathrm{CD} 28: \mathrm{B} 7$ pathway as a regulator of plasma cell function has both stimulatory and inhibitory effects and that the biologic conditions present at the time of antigen exposure determine whether CD28/B7 interactions mediate suppression or augmentation of plasma cell function [41].

To date, we are not aware of any published data on the role of the CD28:B7 axis on plasma cells and alloantibody production in the setting of transplantation. Preliminary observations in our laboratory show strong surface expression of CD28 on allograft-elicited CD19+IgD-B220-CD138+ plasmablasts in the graft-draining lymph nodes of mice following skin transplantation in a full MHC mismatched model (unpublished data). Interestingly, delayed treatment with CD28 costimulation blockade 7 days post-transplant after the majority of Tfh cell differentiation has occurred still prevented the development of DSA [42], corroborating the possibility that CD28 antagonism may be functioning at the B cell level or at an early stage of antibody-secreting cell differentiation in secondary lymphoid organs. While the true clinical significance of these observations remains to be determined, this is a promising area of investigation that may create strong rationale for 
the use of $\mathrm{CD} 28$ pathway blockade for desensitization purposes in cases of early or pre-existing HLA antibodies.

Together, these experimental data in mice and human cells support that CTLA-4-Ig may be exerting a direct effect on B cell lineage cells in addition to its widely accepted effects on $\mathrm{T}$ cells via the CD28:B7 pathway. While the relative role each cell type plays in the various clinical scenarios of sensitization remains to be elucidated, the ostensibly dual impact $\mathrm{CD} 28$ pathway antagonism has on both $\mathrm{T}$ and $\mathrm{B}$ cells only strengthens the rationale for the continued pursuit of costimulation blockade-based strategies as a viable and promising method to combat humoral alloimmunity and the DSA burden in transplantation.

\section{Clinical developments}

Translation of CD28 costimulation blockade into the clinic occurred in 2011 with FDA approval of belatacept for maintenance immunosuppression in kidney transplantation. Although large-scale uptake has been slow due to higher rates of acute rejection and logistical challenges related to monthly i.v. infusion requirements [43], there has been resurgent clinical interest in its consistently observed ability to attenuate alloantibody responses. New reports have continued to document the ability of belatacept to prevent de novo antibody responses, and more recent studies have surfaced exploring its potential to control nascent or pre-existing HLA antibodies.

\section{Prevention of de novo DSA}

Final results from the phase 3 Belatacept Evaluation of Nephroprotection and Efficacy as First-line Immunosuppression Trial (BENEFIT) study analyzing 7year outcomes data reported a significant reduction in the risk of patient death or graft loss with belatacept as compared to the CNI cyclosporine A [13]. Importantly, the results also confirmed that the development of DSA was significantly lower with both the more and less intense belatacept study regimens than with cyclosporine (1.9\% and $4.6 \%$ vs. $17.8 \%$, $P<0.001$, respectively). While the long-term survival benefits observed with belatacept are mostly hypothesized to relate to reduced renal and metabolic toxicities, the lower incidence of anti-donor HLA antibodies with belatacept may be an important contributing factor. In corroboration of this significant reduction in de novo DSA in low immunologic risk clinical trial participants, our group has also observed significantly lower rates of DSA formation ( $4.1 \%$ vs. $8.8 \%, p=0.04)$ along with improved renal function after the adoption of belataceptbased immunosuppressive regimens as standard clinical practice in our general transplant population relative to a historical cohort receiving a tacrolimus-based protocol [44"].
Furthermore, greater in-depth post hoc analysis of patient HLA samples from the BENEFIT and BENEFIT-Extended Criteria Donors (EXT) trials confirmed that the incidence of de novo DSA was significantly lower in belatacept-treated patients versus cyclosporine-treated patients and added that the DSA that occurred in bela patients was of lower median fluorescence intensity (MFI) [45]. Additional post hoc examination of IgM+ de novo DSA recipients experienced a 2.8 times higher rate of conversion to IgG+ de novo DSA on a limited number of patients that will require validation in larger sample sets [46].

Our team is currently concluding a small pilot single-center randomized controlled trial evaluating the ability of belatacept monotherapy to prevent HLA sensitization in re-transplant candidates with failing or failed renal allografts [47]. Immunosuppressive practices in this patient population are highly variable, with many discontinuing immunosuppression and developing HLA antibodies. Given its favorable toxicity profile and ability to prevent alloantibodies, belatacept is an appealing option to minimize sensitization and facilitate retransplantation in this challenging group of patients. Although most re-transplant candidates with failed allografts did develop DSA on belatacept monotherapy, preliminary results indicate that belatacept-treated subjects experience less of an increase in class I and class II PRA, develop fewer and less intense HLA antibodies as measured by cumulative MFIs, and lower cPRA than controls weaned off of immunosuppression. Thus, belatacept monotherapy may reduce the burden of alloantibodies and potentially facilitate re-transplantation and better future outcomes in kidney transplant recipients with failed allografts.

\section{Control of nascent de novo DSA or pre-existing HLA antibodies}

As with the assessment of de novo DSA, our team performed post hoc analyses of stored sera from BENEFIT and BENEFIT-EXT subjects identified to have had pre-existing DSA [48]. Over the first 24 months post-transplant, a greater proportion of pre-existing DSAs in belatacept- versus cyclosporine-treated patients exhibited decreases or no change in MFI. The decline in MFI was more apparent with the more intense than the less intense belatacept-based regimen in both studies. Although derived post hoc, these data suggest that belatacept-based immunosuppression has potential to decrease pre-existing DSAs more effectively than standard CNI-based regimens. Moreover, examination of a multicenter cohort of 163 highly sensitized kidney transplant recipients with cPRA $98-100 \%$ at the time of transplant revealed that belatacept-treated patients experienced decreases in the breadth and/or strength of HLA antibodies as compared to tacrolimus-treated controls [49]. HLA antibody reductions were observed for class I and class II antibodies, along with 
clinically significant reductions in their cPRA values after transplant. Together, these two studies support that CD28 costimulation blockade-based regimens may be preferable to CNI-based regimens in sensitized patients, and the reduction in HLA antibodies in a significant fraction of highly sensitized recipients introduces the possibility of utilizing belatacept to improve pre-transplant compatibility with organ donors.

In line with these observations, it has become our clinical practice to selectively convert transplant recipients that develop DSA early post-transplant from tacrolimus to belatacept. Ulloa et al. retrospectively evaluated the conversion from CNIs to belatacept in 29 HLA-immunized kidney transplant recipients which were converted a median of 444 days after transplantation and followed for a median of 308 days after conversion $\left[50^{\circ}\right]$. At the time of conversion, 16 patients had a total of 19 DSA, all under 3000 MFI except one. At the last follow-up, DSA disappeared in 9 patients, decreased in 5, and moderately increased in 2 with a single episode of antibodymediated rejection. Similarly, the multicenter prospective BELACOR clinical trial examined kidney allograft outcome in transplant recipients with pre-formed DSAs (500-3000 MFI) treated with belatacept [51']. Forty-nine total patients received belatacept-based therapy and were compared to a retrospectively designed ancillary control group treated with calcineurin inhibitors. No episodes of AMR were observed in the belatacept group, and despite higher rates of acute rejection, HLA antibody assessments between groups were similar except a significantly greater number of belatacept-treated patients displayed complete disappearance of class II DSAs. Both these studies have their limitations and require validation in larger, properly controlled prospective trials. They were small and examined recipients with low-grade or subthreshold DSA of unclear pathologic significance. Therefore, while existing data suggests belatacept may work similarly in highly sensitized recipients with DSA [49], this remains to be formally tested. Nonetheless, these studies do support that conversion to belatacept in cases of low-level HLA sensitization is safe and does not result in significant worsening of DSA and may rather protect against antibody-mediated allograft dysfunction along with conferring the added benefit of improved renal function over the long term.

To date, we are not aware of the use of CD28 costimulation blockade with belatacept in formal desensitization protocols. However, attempts to garner the immunosuppressive properties of costimulation blockade on antibody formation are logical next steps in devising new strategies to combat high degrees of pre-existing HLA antibodies, especially considering the potential ability of belatacept to reduce HLA antibodies in highly sensitized transplant recipients as outlined above [49]. Burghuber et al. tested the ability of belatacept to target the upstream GC response in combination with bortezomib desensitization and anti-CD40 therapy in a sensitized NHP kidney transplant model $\left[52^{\circ}\right]$. This regimen successfully mediated reductions in DSA and the cellular components of the humoral response, along with prolongation of graft survival compared to untreated controls. While the investigators observed protective immunity concerns (i.e., viral reactivation of CMV) with this regimen and the effect of belatacept alone without anti-CD40 blockade is unclear, the theoretical framework of utilizing belatacept as a maintenance component of desensitization protocols to target $\mathrm{T}$ and $\mathrm{B}$ cell CD28-driven humoral interactions is a promising future direction.

\section{Conclusions}

The past 20 years have ushered the development and translation of CD28 pathway blockade into clinical kidney transplantation. Although early immunologic and logistical challenges remain for broader scale utilization, the long-term benefits of belatacept and its unique ability to inhibit HLA antibodies should guarantee continued interest in the clinical application of $\mathrm{CD} 28$ pathway blockade. A growing understanding of the mechanisms of anti-CD28-mediated alloantibody inhibition and continued clinical successes will guide the clinical optimization of belatacept and next-generation CD28 blockers already in the development pipeline to prevent and reduce alloantibodies over the long term.

\section{Compliance with Ethical Standards}

Conflict of Interest Raul Badell reports grants from NIH/NIAID (K08 AI132747) during the conduct of the study. Ronald F. Parsons, Christian P. Larsen, and Thomas C. Pearson declare no conflict of interest.

Human and Animal Rights and Informed Consent This article does not contain any studies with human or animal subjects performed by any of the authors.

\section{References}

Papers of particular interest, published recently, have been highlighted as:

- Of importance

•• Of major importance

1. Lodhi SA, Lamb KE, Meier-Kriesche HU. Solid organ allograft survival improvement in the United States: the long-term does not mirror the dramatic short-term success. Am J Transplant. 2011;11(6):1226-35. https://doi.org/10.1111/j.1600-6143.2011. 03539.x.

2. Hart A, Smith JM, Skeans MA, Gustafson SK, Wilk AR, Castro S, et al. OPTN/SRTR 2017 annual data report: kidney. Am J Transplant. 2019;19(Suppl 2):19-123. https://doi.org/10.1111/ajt. 15274 .

3. Nankivell BJ, Borrows RJ, Fung CL, O'Connell PJ, Allen RD, Chapman JR. The natural history of chronic allograft nephropathy. 
N Engl J Med. 2003;349(24):2326-33. https://doi.org/10.1056/ NEJMoa020009.

4. Loupy A, Hill GS, Jordan SC. The impact of donor-specific anti-HLA antibodies on late kidney allograft failure. Nat Rev Nephrol. 2012;8(6):348-57. https://doi.org/10.1038/nrneph. 2012.81.

5. Lefaucheur C, Loupy A, Hill GS, Andrade J, Nochy D, Antoine C, et al. Preexisting donor-specific HLA antibodies predict outcome in kidney transplantation. J Am Soc Nephrol. 2010;21(8):1398-406. https://doi.org/10.1681/ASN.2009101065.

6. Wiebe C, Gibson IW, Blydt-Hansen TD, Karpinski M, Ho J, Storsley LJ, et al. Evolution and clinical pathologic correlations of de novo donor-specific HLA antibody post kidney transplant. Am J Transplant. 2012;12(5):1157-67. https://doi.org/10.1111/j.16006143.2012.04013.x.

7. Djamali A, Kaufman DB, Ellis TM, Zhong W, Matas A, Samaniego M. Diagnosis and management of antibody-mediated rejection: current status and novel approaches. Am J Transplant. 2014;14(2): 255-71. https://doi.org/10.1111/ajt.12589.

8. Jordan SC, Ammerman N, Choi J, Huang E, Peng A, Sethi S, et al. Novel therapeutic approaches to allosensitization and antibodymediated rejection. Transplantation. 2019;103(2):262-72. https:// doi.org/10.1097/TP.0000000000002462.

9. Linsley PS, Wallace PM, Johnson J, Gibson MG, Greene JL, Ledbetter JA, et al. Immunosuppression in vivo by a soluble form of the CTLA-4 T cell activation molecule. Science. 1992;257(5071):792-5.

10. Larsen CP, Pearson TC, Adams AB, Tso P, Shirasugi N, Strobert E, et al. Rational development of LEA29Y (belatacept), a high-affinity variant of CTLA4-Ig with potent immunosuppressive properties. Am J Transplant. 2005;5(3):443-53. https://doi.org/10.1111/j. 1600-6143.2005.00749.x.

11. Badell IR, Russell MC, Cardona K, Shaffer VO, Turner AP, Avila JG, et al. CTLA4Ig prevents alloantibody formation following nonhuman primate islet transplantation using the CD40-specific antibody 3A8. Am J Transplant. 2012;12(7):1918-23. https://doi.org/ 10.1111/j.1600-6143.2012.04029.x.

12. Vanrenterghem Y, Bresnahan B, Campistol J, Durrbach A, Grinyo $\mathrm{J}$, Neumayer $\mathrm{HH}$, et al. Belatacept-based regimens are associated with improved cardiovascular and metabolic risk factors compared with cyclosporine in kidney transplant recipients (BENEFIT and BENEFIT-EXT studies). Transplantation. 2011;91(9):976-83. https://doi.org/10.1097/TP.0b013e31820c10eb.

13.• Vincenti F, Rostaing L, Grinyo J, Rice K, Steinberg S, Gaite L, et al. Belatacept and long-term outcomes in kidney transplantation. $\mathrm{N}$ Eng1 J Med. 2016;374(4):333-43. https://doi.org/10.1056/ NEJMoa1506027 Seven year results of phase III BENEFIT Study showing a significant improvement in long-term kidney transplant outcomes with belatacept.

14. Ford ML, Kirk AD, Larsen CP. Donor-reactive T-cell stimulation history and precursor frequency: barriers to tolerance induction. Transplantation. 2009;87(9 Suppl):S69-74. https://doi.org/10. 1097/TP.0b013e3181a2a701.

15. Ford ML, Larsen CP. Translating costimulation blockade to the clinic: lessons learned from three pathways. Immunol Rev. 2009;229(1):294-306. https://doi.org/10.1111/j.1600-065X.2009. 00776.x.

16. Badell IR, Karadkhele GM, Vasanth P, Farris AB, 3rd, Robertson JM, Larsen CP. Abatacept as rescue immunosuppression after calcineurin inhibitor treatment failure in renal transplantation. Am J Transplant. 2019;19(8):2342-9. https://doi.org/10.1111/ajt.15319.

17. Vanhove B, Poirier N, Soulillou JP, Blancho G. Selective costimulation blockade with antagonist anti-CD28 therapeutics in transplantation. Transplantation. 2019. https://doi.org/10.1097/TP. 0000000000002740 .
18. Shahinian A, Pfeffer K, Lee KP, Kundig TM, Kishihara K, Wakeham A, et al. Differential T cell costimulatory requirements in CD28-deficient mice. Science. 1993;261(5121):609-12.

19. Ferguson SE, Han S, Kelsoe G, Thompson CB. CD28 is required for germinal center formation. J Immunol. 1996;156(12):4576-81.

20. Crotty $\mathrm{S}$. T follicular helper cell differentiation, function, and roles in disease. Immunity. 2014;41(4):529-42. https://doi.org/10.1016/j. immuni.2014.10.004.

21. Lafferty KJ, Cunningham AJ. A new analysis of allogeneic interactions. Aust J Exp Biol Med Sci. 1975;53(1):27-42.

22. Badell IR, Ford ML. T follicular helper cells in the generation of alloantibody and graft rejection. Curr Opin Organ Transplant. 2016;21(1):1-6. https://doi.org/10.1097/MOT. 0000000000000260 .

23. Walters GD, Vinuesa CG. T follicular helper cells in transplantation. Transplantation. 2016;100(8):1650-5. https://doi.org/10.1097/ TP.0000000000001217.

24. Kim I, Wu G, Chai NN, Klein AS, Jordan SC. Immunological characterization of de novo and recall alloantibody suppression by CTLA4Ig in a mouse model of allosensitization. Transpl Immunol. 2016;38:84-92. https://doi.org/10.1016/j.trim.2016.08.001.

25. Kim EJ, Kwun J, Gibby AC, Hong JJ, Farris AB 3rd, Iwakoshi NN, et al. Costimulation blockade alters germinal center responses and prevents antibody-mediated rejection. Am J Transplant. 2014;14(1):59-69. https://doi.org/10.1111/ajt.12526 Pre-clinical study demonstrating an association between altered germinal center responses and CD28 costimulation blockade-mediated DSA inhibition in primate transplant model.

26. Ford ML, Adams AB, Pearson TC. Targeting co-stimulatory pathways: transplantation and autoimmunity. Nature Reviews Nephrology. 2014;10(1):14-24. https://doi.org/10.1038/nrneph. 2013.183.

27. Tivol EA, Borriello F, Schweitzer AN, Lynch WP, Bluestone JA, Sharpe AH. Loss of CTLA-4 leads to massive lymphoproliferation and fatal multiorgan tissue destruction, revealing a critical negative regulatory role of CTLA-4. Immunity. 1995;3(5):541-7.

28.• Sage PT, Paterson AM, Lovitch SB, Sharpe AH. The coinhibitory receptor CTLA-4 controls B cell responses by modulating T follicular helper, $\mathrm{T}$ follicular regulatory, and $\mathrm{T}$ regulatory cells. Immunity. 2014;41(6):1026-39. https://doi.org/10.1016/j.immuni. 2014.12.005 Basic science study identifying intrinsic role of CTLA-4 on $T$ cells to control $T$ cell dependent antibody responses.

29.• Wing JB, Ise W, Kurosaki T, Sakaguchi S. Regulatory T cells control antigen-specific expansion of Tfh cell number and humoral immune responses via the coreceptor CTLA-4. Immunity. 2014;41(6):1013-25. https://doi.org/10.1016/j.immuni.2014.12. 006 Basic science study highlighting CTLA-4 mediated control of $\mathrm{Tfh}$ cells and humoral response by regulatory $\mathrm{T}$ cells.

30. Badell IR, La Muraglia GM 2nd, Liu D, Wagener ME, Ding G, Ford ML. Selective CD28 blockade results in superior inhibition of donor-specific $\mathrm{T}$ follicular helper cell and antibody responses relative to CTLA4-Ig. Am J Transplant. 2018;18(1):89-101. https:// doi.org/10.1111/ajt.14400 Basic science study demonstrating that next generation selective CD28 blockade is superior to CTLA-4-Ig at inhibiting DSA in a murine transplant model.

31. Ville S, Poirier N, Branchereau J, Charpy V, Pengam S, NerriereDaguin V, et al. Anti-CD28 antibody and belatacept exert differential effects on mechanisms of renal allograft rejection. J Am Soc Nephrol. 2016;27(12):3577-88. https://doi.org/10.1681/ASN. 2015070774.

32. La Muraglia GM 2nd, Wagener M, Ford ML, Badell IR. ICOS+PD$1+$ circulating $\mathrm{T}$ follicular helper cells are a biomarker of humoral alloreactivity and predict donor-specific antibody generation following transplantation. Am J Transplant. 2019;19(S3). 
33. Chen J, Yin H, Xu J, Wang Q, Edelblum KL, Sciammas R, et al. Reversing endogenous alloreactive $\mathrm{B}$ cell $\mathrm{GC}$ responses with antiCD154 or CTLA-4Ig. Am J Transplant. 2013;13(9):2280-92. https://doi.org/10.1111/ajt.12350.

34. Chen J, Wang Q, Yin D, Vu V, Sciammas R, Chong AS. Cutting edge: CTLA-4Ig inhibits memory B cell responses and promotes allograft survival in sensitized recipients. J Immunol. 2015;195(9): 4069-73. https://doi.org/10.4049/jimmunol.1500940 Pre-clinical study showing that CTLA-4-Ig capable of abrogating memory $B$ cell responses and heart allograft rejection in sensitized mice.

35. Young JS, Chen J, Miller ML, Vu V, Tian C, Moon JJ, et al. Delayed cytotoxic T lymphocyte-associated protein 4immunoglobulin treatment reverses ongoing alloantibody responses and rescues allografts from acute rejection. Am J Transplant. 2016;16(8):2312-23. https://doi.org/10.1111/ajt.13761.

36. Leibler C, Thiolat A, Henique C, Samson C, Pilon C, Tamagne M, et al. Control of humoral response in renal transplantation by belatacept depends on a direct effect on $\mathrm{B}$ cells and impaired $\mathrm{T}$ follicular helper-B cell crosstalk. J Am Soc Nephrol. 2018;29(3): 1049-62. https://doi.org/10.1681/ASN.2017060679.

37.• Rozanski CH, Arens R, Carlson LM, Nair J, Boise LH, ChananKhan AA, et al. Sustained antibody responses depend on CD28 function in bone marrow-resident plasma cells. J Exp Med. 2011;208(7):1435-46. https://doi.org/10.1084/jem.20110040 Elegant study demonstrating that long-lived plasma cells and sustained antibody responses are dependent on CD28-mediated pro-survival signals.

38. Rozanski CH, Utley A, Carlson LM, Farren MR, Murray M, Russell LM, et al. CD28 promotes plasma cell survival, sustained antibody responses, and BLIMP-1 upregulation through its distal PYAP proline motif. J Immunol. 2015;194(10):4717-28. https:// doi.org/10.4049/jimmunol.1402260.

39. Halliley JL, Tipton CM, Liesveld J, Rosenberg AF, Darce J, Gregoretti IV, et al. Long-lived plasma cells are contained within the CD19(-)CD38(hi)CD138(+) subset in human bone marrow. Immunity. 2015;43(1):132-45. https://doi.org/10.1016/j.immuni. 2015.06.016.

40. Njau MN, Kim JH, Chappell CP, Ravindran R, Thomas L, Pulendran B, et al. CD28-B7 interaction modulates short- and long-lived plasma cell function. J Immunol. 2012;189(6):275867. https://doi.org/10.4049/jimmunol.1102728.

41. Njau MN, Jacob J. The CD28/B7 pathway: a novel regulator of plasma cell function. Advances in experimental medicine and biology. 2013;785:67-75. https://doi.org/10.1007/978-1-4614-6217-0_ 8.

42. La Muraglia GM 2nd, Ford ML, Badell IR. Selective CD28 blockade-mediated inhibition of T follicular helper cell and DSA responses is CTLA-4 dependent. Am J Transplant. 2019;19(S3).

43. Heher E, Markmann JF. The clearer BENEFITS of belatacept. N Engl J Med. 2016;374(4):388-9. https://doi.org/10.1056/ NEJMe1515765.

44. Adams AB, Goldstein J, Garrett C, Zhang R, Patzer RE, Newell $\mathrm{KA}$, et al. Belatacept combined with transient calcineurin inhibitor therapy prevents rejection and promotes improved long-term renal allograft function. Am J Transplant. 2017;17(11):2922-36. https:// doi.org/10.1111/ajt.14353 Largest off-trial clinical experience reporting superior renal allograft function and DSA reduction with belatacept-based immunosuppression following kidney transplantation.

45. Bray RA, Gebel HM, Townsend R, Roberts ME, Polinsky M, Yang $\mathrm{L}$, et al. De novo donor-specific antibodies in belatacept-treated vs cyclosporine-treated kidney-transplant recipients: post hoc analyses of the randomized phase III BENEFIT and BENEFIT-EXT studies. Am J Transplant. 2018;18(7):1783-9. https://doi.org/10.1111/ajt. 14721.

46. Everly MJ, Roberts M, Townsend R, Bray RA, Gebel HM. Comparison of de novo IgM and IgG anti-HLA DSAs between belatacept- and calcineurin-treated patients: an analysis of the BENEFIT and BENEFIT-EXT trial cohorts. Am J Transplant. 2018;18(9):2305-13. https://doi.org/10.1111/ajt.14939.

47. Badell IR, Elbein R, Bray RA, Gebel HM, Adams AB, Larsen CP. Belatacept monotherapy in kidney transplant recipients with failed allografts reduces humoral sensitization in a single center randomized controlled trial. Am J Transplant. 2019;19(S3).

48. Bray RA, Gebel HM, Townsend R, Roberts ME, Polinsky M, Yang $\mathrm{L}$, et al. Posttransplant reduction in preexisting donor-specific antibody levels after belatacept- versus cyclosporine-based immunosuppression: post hoc analyses of BENEFIT and BENEFIT-EXT. Am J Transplant. 2018;18(7):1774-82. https://doi.org/10.1111/ajt. 14738.

49. Parsons RF, Zahid A, Bumb S, Decker H, Sullivan HC, Eun-Hyung Lee $\mathrm{F}$ et al. The impact of belatacept on third-party HLA alloantibodies in highly sensitized kidney transplant recipients. Am J Transplant. 2019. https://doi.org/10.1111/ajt.15585.

50. Ulloa CE, Anglicheau D, Snanoudj R, Scemla A, Martinez F, Timsit MO, et al. Conversion from calcineurin inhibitors to belatacept in HLA- sensitized kidney-transplant recipients with low-level donor specific antibodies. Transplantation. 2019. https:// doi.org/10.1097/TP.0000000000002592 Retrospective analysis of sensitized kidney transplant recipients safely converted to belatacept post-transplant.

51. Leibler C, Matignon M, Moktefi A, Samson C, Zarour A, Malard S, et al. Belatacept in renal transplant recipient with mild immunologic risk factor: a pilot prospective study (BELACOR). Am J Transplant. 2019;19(3):894-906. https://doi.org/10.1111/ajt.15229 Prospective pilot clinical trial examining the use of belataceptbased immunosuppression in lowly sensitized kidney transplant recipients with pre-formed DSA.

52. Burghuber CK, Manook M, Ezekian B, Gibby AC, Leopardi FV, Song M, et al. Dual targeting: combining costimulation blockade and bortezomib to permit kidney transplantation in sensitized recipients. Am J Transplant. 2019;19(3):724-36. https://doi.org/10. 1111/ajt.15067 Pre-clinical study utilizing belatacept-based immunosuppression as a desensitization strategy in sensitized nonhuman primates to faciliate kidney transplantation.

Publisher's Note Springer Nature remains neutral with regard to jurisdictional claims in published maps and institutional affiliations. 